\title{
Determination of Black Site Area Based on Equivalent Accident Number Analysis: Case Study National Roads in Ambon City
}

\author{
Lenora Leuhery, Hamkah* \\ Department of Civil Engineering, Politeknik Negeri Ambon, Indonesia
}

Received August 18, 2020; Revised September 25, 2020; Accepted October 19, 2020

\begin{abstract}
Cite This Paper in the following Citation Styles
(a): [1] Lenora Leuhery, Hamkah, "Determination of Black Site Area Based on Equivalent Accident Number Analysis: Case Study National Roads in Ambon City," Civil Engineering and Architecture, Vol. 8, No. 5, pp. 1063 - 1073, 2020. DOI: 10.13189/cea.2020.080533.
\end{abstract}

(b): Lenora Leuhery, Hamkah (2020). Determination of Black Site Area Based on Equivalent Accident Number Analysis: Case Study National Roads in Ambon City. Civil Engineering and Architecture, 8(5), 1063 - 1073. DOI: 10.13189/cea.2020.080533.

Copyright $\odot 2020$ by authors, all rights reserved. Authors agree that this article remains permanently open access under the terms of the Creative Commons Attribution License 4.0 International License

\begin{abstract}
This study was conducted to determine accident-prone areas (black sites) on national roads in Ambon City using the Equivalent Accident Number (EAN) and Upper Control Limit (UCL) criteria. Primary data was obtained by direct survey. Meanwhile, secondary data was obtained from various sources related to the number of traffic accidents in Ambon City. The data were analyzed using simple statistical methods and tabulated based on the number of accidents in 2019. The analysis results showed that the high severity of traffic accidents in Ambon City was $91.95 \%$ caused by driver behavior factors. Three other factors that cause traffic accidents include drunkenness, carelessness, and drowsiness. The study results showed five black site areas on national roads in Ambon City based on EAN value higher than the UCL value. These locations include roads: Jenderal Sudirman, Pierre Tendean, Wolter Monginsidi, Laksdya Leo Wattimena, and Putuhena. Meanwhile, the Sisingamangaraja road segment has a higher EAN value than the UCL value but not the national road segment (province road segment). Based on these results, several things need to be done to overcome the accident rate. Therefore, national road management agencies and stakeholders, especially those related to the black site area, are advised to: build road medians, add zebra cross-shaped crossing facilities and be equipped with shelters in the road median, complete traffic signs installed with signs that read accident-prone area, build pedestrian protective fences, and traffic management engineering.
\end{abstract}

Keywords Black Site, EAN, UCL, Traffic Accidents Prone, National Road Segment, Ambon City

\section{Introduction}

Traffic accidents are a severe problem for many developing countries in the world. Under vehicle growth not followed by a good road infrastructure improvement [1] will affect the accident rate significantly. In Indonesia, high accident rates occur in big cities [2], [3], and Ambon City is no exception. To reduce the accidents number and victim fatalities, WHO (2006) established the Global Road Safety Partnership (GRSP) [4]. United Nations member states asked to formulate short-term and long-term strategic policies in minimizing the number and consequences of road accidents. According to the Ministry of Transportation (2010), 90\% of accident cases occur in developing countries like Indonesia [4].

Meanwhile, in 2019 the Indonesian National Police recorded 107,500 traffic accidents, increasing 3\% from 2018, as many as 103,672 accidents [5]. Indonesia's commitment to the United Nations Decade of Road Safety Action is required by establishing a National General Plan for Traffic and Land Transportation Safety, aiming to reduce the fatalities rate due to traffic accidents by $50 \%$ in 
2020 [4]. Various efforts were made to improve the traffic system by involving related parties, reduce traffic accident victims' numbers and continuously create safe traffic.

One effort to reduce the accident rate is the road safety campaign [6]. Accidents prone areas based on road type in Surabaya City are roads with type 4/2UD [6]. Therefore, for Ambon City with 35 segments, there are only 5 points with a very worrying median [4]. The lack of knowledge and information of the community regarding road signs and markings increases accident risk.

An appropriate analysis or study is needed to determine accident-prone areas' locations and characteristics in Ambon City. Three components were interrelated with traffic operations in improving traffic safety on the road: drivers, vehicles, and roads. Vehicles have a profound effect on accident causes. However, elements of road geometry such as section length, number of lanes, and horizontal curves significantly impact the incidence of accidents. Most of the accident victims found in a very productive age group. The age of group people ranges of 15 to 49 years old.

Identifying, analyzing, and improving accident-prone areas were the most critical accident prevention [7]. The studies related to accident-prone areas were carried out in two districts in Hanoi-Vietnam, concluding that the accident data were summarized and illustrated in the Vietnam police ledger. It is causing difficulties to evaluate accidents. Another study conducted in the Republic of Srpska on traffic safety between 2012 and 2017 concluded that in addition to the accident level, regulatory issues, accident costs, and performance audits should also be considered [8]. Pedestrian safety is also important to note. Installing speed tables on roads can reduce the pedestrian accidents rate to zero [9]. Traffic safety is also affected by the minimum road distance. A study on determining the minimum length of entry and exit of an incline a toll road in Indonesia shows that the resulting minimum road distance for the 4-lane case of fatal accident model is $6 \mathrm{~km}$; for injuries accidents is $5 \mathrm{~km}$, and the total accident is $4 \mathrm{~km}$ [10]. However, an accident schema symbol system and cause accident analysis seem more accessible and more effective [11]. The random accident location analysis ranking based on the Weighted Accident Number (WAN) value was studied and concluded that the National Road in Lampung Province indicated five accident-prone areas [12]. The study of black spot analysis using the EAN and UCL methods in Kupang City revealed two locations identified as accident-prone areas. [13].

Besides, the study evaluated of responsible riding program on reducing the motorcycle accident rate. The traffic safety campaign program for road users in Surabaya City was carried out by the Surabaya Police, Surabaya Police Satlantas Unit, and Jawa Pos on several major road users in Surabaya. The campaign focuses on road safety standards such as: using an Indonesian standard helmet (SNI), not driving beyond the $40 \mathrm{~km} /$ hour speed limit, not making zigzag paths and prioritizing vehicles already on their track, not using cellphones when driving, not violating traffic lights, and crossing on zebra crossing has shown a significant result in reducing the rate of motorcycle accidents [14].

Various results of this study can be used as a reference in reducing motorized accident risk, given the lack of information and knowledge of the Ambon City community about safety riding, reading traffic signs, and road markings [4]. This study is expected to contribute valuable information as a public warning to be more careful when driving and for related agencies to plan better and more precise handling efforts reducing traffic accidents risk in Ambon City. Therefore, this study aims to examine traffic accidents causes in Ambon City and calculate their severity. It intended to update data on accident-prone areas based on several previous studies as traffic accident data on the prone area are located and solution recommendations, particularly in Ambon City national roads.

\section{Literature Review}

\subsection{Definition of a Traffic Accident}

Traffic accidents are part work of accidents. According to Indonesia government regulations No. 34 (1993): a road accident involving a vehicle with or without other road users, resulting in human casualties or property loss. Meanwhile, according to Indonesian Law No. 3 (1995): traffic accidents are the final events of unintentional events series in death, serious/minor injuries, disabilities, and material loss, or object damage occur on public roads. According to WHO, a traffic accident occurs when a motorized vehicle collides with another object and causes damage. The incident resulted in death or injury to humans and animals.

Based on these three definitions, the traffic accident is an unexpected, unplanned, and sudden accident occurring on the highway due to the road's human activity error. Accidents cause injury, illness, and loss, both to humans, property, and the environment. Traffic accident victims are humans due to traffic accidents. The severity of accident victims (casualty) is divided into fatality killed, serious injuries, and minor injuries.

\subsection{Factors Causing Accidents}

A traffic accident is caused by many factors, basically due to the ineffective combination of four main factors: Human, Environment, Road, and Vehicle [15]. To regulate these four main elements, laws, regulations, and standards governing traffic safety requirements are required.

According to article 1, Indonesian government regulations No. 44 (1993) regarding vehicles and drivers, such as road traffic and transportation law regulation. A 
driver is a person who drives a motorized vehicle or a person who directly supervises a prospective driver who is learning to drive a motorized vehicle. Vehicle drivers, both motorized and non-motorized vehicles, are the leading causes of accidents, so they need attention.

Vehicles are devices that can move on the road, consisting of motorized and non-motorized vehicles. A motorized vehicle is a vehicle that is driven by technical equipment located in that vehicle. Motorized vehicles can group into motorbikes, passenger cars, buses, goods cars, and special vehicles. Every motorized vehicle must equip with braking equipment, which includes the primary and parking brake and has a wheel system that consists of the wheels and axles. Besides the wheel system, a motorized vehicle also has a suspension in support that can withstand loads, vibrations, and shocks to ensure safety and protection for its users. Additional lights on motorized cars can reduce the risk of accidents.

The road properties and condition are very influential as a traffic accidents cause. Improvement of road conditions affects accident properties. Roads are designed and maintained for safety and based on analysis results of road function, traffic volume, composition, design speed, topography, human factors, vehicle weight and size, social environment, and funds [16]. If the implementation is forced to deviate from the standard provisions, information on accident-prone areas must post immediately before a road is open to the public. Also, in prone locations, an explicit notification must be given about the road condition so that drivers know the surrounding circumstances and more careful.

The geometric road planning must account for the traffic that will pass on the road, the road slope, the horizontal alignment, the intersections, and the cross-section components. The information can be road dividing line form specially used at night, equipped with reflective paint, roadside posts, cat's eyes, and markers with reflective paint.

\subsection{Traffic Accident Severity}

A traffic accident victim is a person who is a victim of a traffic accident. In general, the severity caused by traffic accidents is divided into three types: 1) death (fatal), 2) serious injury, and 3) minor injury. An accident that does not involve other road users is called a single accident. Besides, there are still traffic accidents without casualties, namely accidents with only property loss (only property damage $=$ PDO accidents). The impact of traffic accidents based on an injury can be classified into four levels. A fatal accident is an accident victim confirmed due to a traffic accident within 30 days after the accident. Serious Accidents are victims of accidents due to injuries sustained by permanent disabilities or must hospitalize within 30 days from the accident. An event is a lifelong disability if a limb is lost or cannot be used and cannot recover forever. Minor Accidents are accidents that do not require hospitalization for 30 days, only causing material loss.

\subsection{Equivalent Accident Number (EAN)}

The equivalent accident number use for weighting accident class based on accident value with material damage or loss. The EAN is an economy scale weighing accident rates. It is calculated by comparing estimated economic losses caused by different accident levels, i.e., death (M), serious injury (B), minor injury (R), or only property damaged $(\mathrm{K})$. The technique of identifying accident ratings carried out by determining accident weight. There are several types of accidents based on victim severity. So that way, the accident number is synchronized to become an accident weight. The weight value depends on the method used. In Indonesia, some analysis techniques used are as follows. First, the collision equivalent number with a weighting system refers to accident cost (Engineering Committee for Standardization of Transportation Infrastructure, 2004): M: B: R: K= 12: 3: 3: $1 ; 2)$. Secondly, Accident Point Weightage (APW) method. The method divides severity level into four main categories, one of them having the following weights [17]: M: B: R: K = 6: 3: 0.8: 0.2. Third, the equivalent accident number is calculated by adding up accidents for each kilometer of road length and then multiplying the weight value according to the severity. Standard weights used are [18]: M: B: R: K=12: 6: 3: 1; 4). Fourth, the Indonesian Police's collision equivalent number: $\mathrm{M}: \mathrm{B}: \mathrm{R}: \mathrm{K}=10: 5: 1: 1$. Therefore, there are several recommended EAN values for determining accident-prone areas. The EAN value uses a rationalized average cost, as shown in Table 1.

Table 1. Equivalent Accident Number (EAN)

\begin{tabular}{cccccc}
\hline \multirow{2}{*}{ The Severity } & \multicolumn{2}{c}{ Methods } & The Average of \\
\cline { 2 - 6 } & $\begin{array}{c}\text { Research and } \\
\text { Development Center }\end{array}$ & APW & Indonesian Police & $\begin{array}{c}\text { Land } \\
\text { Transportation }\end{array}$ & \begin{tabular}{c} 
Rationalization \\
\hline Death (M)
\end{tabular} \\
\hline Major (B) & 3 & 6 & 10 & 12 & 10 \\
\hline Minor (R) & 3 & 3 & 5 & 6 & 4.25 \\
\hline Material Loss $(\mathbf{K})$ & 1 & 0.8 & 1 & 1 & 1.95 \\
\hline
\end{tabular}


In Indonesia, several recent studies related to the determination of accident-prone areas for several large cities using the EAN criteria have been carried out. Arung and Widyastuti (2020) surveyed the accident-prone area in the City of Surabaya and produced three roads as black site areas: Ahmad Yani, Mastrip, and Ir. Soekarno [19]. Pradana et al. (2019) has reported an analysis of traffic accidents and their causes on the Cilegon highway. The study results show that three roads have an EAN value greater than UCL [20]. Also, Widiyanti (2016) has reported the results of a study on accident-prone areas using EAN and UCL in the Banyuasin Regency. The survey results using the EAN method show the black site on the Palembang-Jambi road section [21].

\subsection{Upper Limit Control (UCL)}

Determination of the accident-prone area using statistics with the Upper Control Limit (UCL) method as shown in Equation 1.

$$
U C L=\lambda+\psi x \sqrt{\left(\frac{\lambda}{m}+\frac{0,829}{m}+\left(\frac{1}{2} x m\right)\right)}
$$

Where:

$\lambda=$ Average accident rate per exposure

$\psi=$ Probability Factor $=2,576$

$m=$ Exposure Units, in kilometers

Road segments with an accident value (EAN) above UCL are defined as accident-prone areas. The probability factor $(\mathrm{y})$ value is determined as a large accident rate that cannot be considered a random event. The probability factor (y) is shown in Table 2. The most commonly used values are 2,576 with a probability of 0.005 (or $99.5 \%$ significance) and 1.645 with a possibility of 0.05 (or $95 \%$ significance). The UCL criteria are one of the methods used to determine accident-prone areas. The other techniques are accident frequency, accident rate, equivalent accident number, Z-score, and cumulative summary.

The UCL method is commonly used in Indonesia; it is shown by several previous studies that have used this method [19-21]. The results obtained using several analytical methods offer the same black site area, but the calculated value of each is different depending on the criteria used.

\subsection{Accident-Prone Area}

Accident-prone areas have the highest accident rate, the highest accident risk, and the road's highest accident potential. Accident-prone areas identified on certain roads are known as black sites. The general criteria that can use to define a black spot are; a) has a high accident rate; b) the accident location is relatively accumulated; c) accidents occurred in somewhat the same space and period; d) have a specific cause of the accident.

\section{Methodology of Study}

\subsection{Location of Study}

The study location on traffic accident severity and accident-prone areas (black sites and black spots) is the national road connecting Yos Sudarso Port and Pattimura Airport in Ambon City. Also, Pattimura Airport and Hunimua Ferry Pier in Central Maluku Regency [22] are shown in Figure 1.

\subsection{The Steps of Study}

This activity is carried out in a structured and systematic manner with stages according to scientific studies. Generally, it includes 1) Determine goals and objectives to be achieved solutions accident-prone areas on national roads in Ambon City. 2) A literature study is a stage of tracing suitable theoretical sources and becomes a reference in conducting various analyzes. 3) The study method is the stage of implementing the study according to the sequence of activities. 4) Accident-prone areas study discusses black site areas in the national road accident-prone areas in Ambon City, and 5) Conclusions and recommendations are conclusions that present a summary of the study results and the solutions to the findings in the form of advice. 


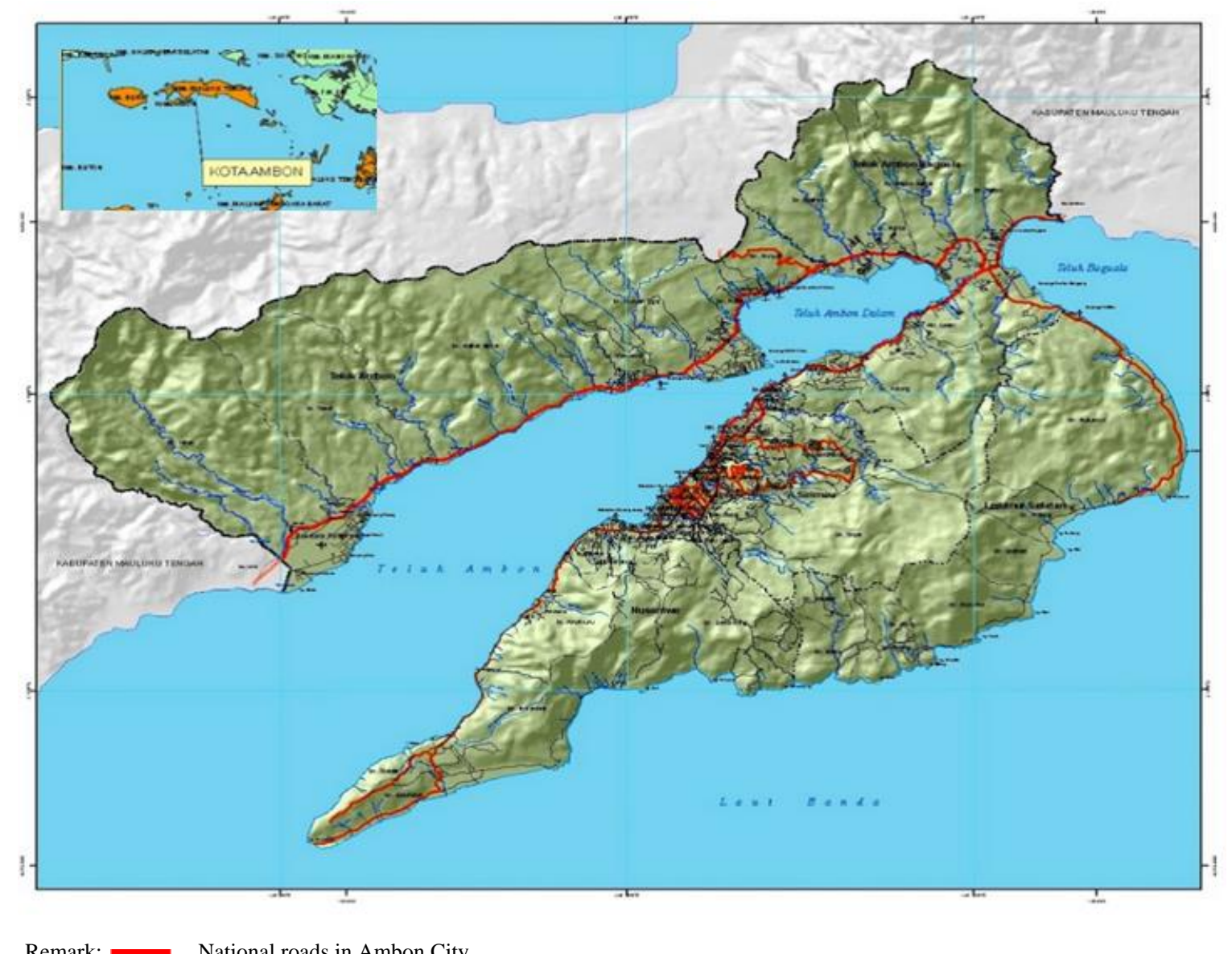

Figure 1. Road network map in Ambon City

\section{Result and Discussion}

\subsection{Traffic Accident of Ambon City Based on 2019 Data}

Based on several references and data sources, accident data on national roads in Ambon City during 2019 is tabulated according to the road segment names and the accident's month. Table 2 presents traffic accidents number according to the month of occurrence for 35 roads, including national highways status in Ambon City. Four hundred sixty-eight incidents represent accident numbers from January to December of 35 roads segment in Ambon City.

Based on the accident number, the black site area is classified as a five national road segment, each have a description of the highest total events as follows: Jenderal Sudirman (34 incidents), Pierre Tendean (28 incidents), Laksdya Leo Wattimena (28 incidents), Ir. M. Putuhena (27 incidents), and Wolter Monginsidi (23 incidents). Sisingamangaraja road, although the total number of 22 incidents is relatively high, is not yet classified as a black site area. It still depends on the EAN calculation and not national road status.

The human casualty severity data, a breakdown according to minor injuries, serious injuries, and deaths are presented in Table 3 . The death fatality, which is the worst result of a traffic accident described based on the national road segment and accident rate each month, as follows: Jenderal Soedirman six months (February, March, July, August, September, and October), Pierre Tendean four months (April, June, July, August), Wolter Monginsidi six months (January, April, May, October, November, December), Laksdya Leo Wattimena six months (April, July, September, October, November), Ir. M. Putuhena, eight months (January, February, March, April, May, September, November, December). The severity of Sisingamangaraja road is high for five months, but it is not classified as a black site (not national road status). Therefore, the five black site areas above ranked as the highest accident number, and roads cause the highest severity (death). 
Table 2. The traffic accidents number in 2019 of Ambon City

\begin{tabular}{|c|c|c|c|c|c|c|c|c|c|c|c|c|c|c|}
\hline Road Segment & $\begin{array}{c}\text { Segment } \\
\text { Length } \\
(\mathrm{km}) \\
\end{array}$ & Jan & Feb & Mar & Apr & May & Jun & Jul & Aug & Sep & Oct & Nov & Dec & Total \\
\hline Amahusu & 11.58 & 2 & 1 & 2 & & 2 & 2 & & 3 & 1 & 2 & 1 & 1 & 17 \\
\hline Dr. Malaiholo & 1.62 & 4 & 2 & & 3 & 2 & & & 2 & 2 & 1 & & 3 & 19 \\
\hline Dr. Kayadoe & 1.49 & & & 3 & & & 1 & & & 2 & 2 & 1 & 1 & 10 \\
\hline Dr. Tamaela & 0.35 & & 3 & 1 & 2 & & 1 & & 1 & & 1 & 1 & 1 & 11 \\
\hline Diponegoro & 0.62 & & & 1 & 4 & & & 2 & & 1 & 1 & & 2 & 11 \\
\hline Ahmad Yani & 0.54 & & & & & & 2 & & 3 & & 1 & & & 6 \\
\hline Rijaly & 0.64 & 1 & 1 & & 2 & & & 2 & & & 2 & 1 & & 9 \\
\hline $\begin{array}{c}\text { Jenderal } \\
\text { Soedirman }\end{array}$ & 2.90 & & 4 & 3 & 5 & 3 & 1 & 4 & 2 & 3 & 2 & 1 & 6 & 34 \\
\hline Pierre Tendean & 3.30 & 2 & 3 & 1 & 1 & 2 & 3 & 2 & 1 & 1 & 5 & 2 & 5 & 28 \\
\hline $\begin{array}{c}\text { Wolter } \\
\text { Monginsidi }\end{array}$ & 4.24 & 1 & 2 & 1 & 2 & 4 & 3 & & 3 & & 2 & 3 & 2 & 23 \\
\hline $\begin{array}{l}\text { Laksdya Leo } \\
\text { Wattimena }\end{array}$ & 5.61 & 1 & 1 & & 3 & 4 & 2 & 1 & & 3 & 5 & 3 & 5 & 28 \\
\hline Ir. M. Putuhena & 9.23 & 1 & 2 & 2 & 1 & 2 & 3 & 2 & 1 & 2 & 3 & 3 & 5 & 27 \\
\hline Syaranamual & 3.42 & & 2 & 1 & 1 & & & 2 & & & 3 & & 6 & 15 \\
\hline Sisingamangaraja & 3.25 & 6 & 1 & 1 & & & 3 & & 1 & 2 & 4 & 2 & 2 & 22 \\
\hline Dr. Leimena & 3.05 & 1 & 1 & & 2 & 3 & & 3 & & & 2 & 3 & 3 & 18 \\
\hline Dr. Siwabessy & 0.96 & 1 & 3 & 2 & & 3 & 1 & 1 & & & 3 & 2 & 1 & 17 \\
\hline $\begin{array}{c}\text { Philip } \\
\text { Latumahina }\end{array}$ & 0.41 & & & & & & 2 & 1 & & 1 & 1 & 1 & 1 & 7 \\
\hline Dr. Sitanala & 0.35 & 1 & & 1 & & & & & 3 & & 1 & 1 & 1 & 8 \\
\hline Sultan Baabulah & 0.63 & & 1 & 2 & 1 & 1 & & & & 1 & 2 & 2 & 1 & 11 \\
\hline A.Y. Patty & 0.46 & 1 & 2 & 2 & 1 & 1 & 2 & 2 & 1 & 1 & 1 & 2 & 1 & 17 \\
\hline Said Perintah & 0.39 & & 1 & & & & 1 & & 1 & 1 & 1 & & 1 & 6 \\
\hline Pattimura & 0.55 & 1 & 3 & 1 & 2 & 1 & 1 & & & 2 & 2 & 3 & 3 & 19 \\
\hline Wem Reawaru & 0.18 & 3 & 1 & 1 & & & 3 & 1 & 1 & & 1 & & 1 & 12 \\
\hline Sultan Khairun & 0.47 & & 1 & & 2 & & & 2 & & 1 & & 2 & & 8 \\
\hline Kakialy & 0.29 & 1 & & 1 & & 1 & & 2 & 1 & & 1 & & 1 & 8 \\
\hline Tulukabessy & 0.39 & & 2 & & & & 2 & & & 1 & & 2 & & 7 \\
\hline $\begin{array}{c}\text { Sultan } \\
\text { Hasanuddin }\end{array}$ & 2.46 & & & & & & & 2 & & & 1 & & 2 & 5 \\
\hline Setia Budi & 0.53 & & & & 1 & & 1 & & 1 & & 1 & & 2 & 6 \\
\hline W.R.Suprtaman & 0.25 & & & & & & & 1 & & 1 & & 1 & & 3 \\
\hline Kapitan Ulupaha & 0.17 & 1 & & 1 & & 2 & & 1 & 1 & & 2 & & 1 & 9 \\
\hline Jan Paays & 0.31 & & & & 1 & & 1 & 2 & & 1 & 1 & & 1 & 7 \\
\hline A.M. Sangadji & 0.26 & & 2 & & 3 & & 2 & & 1 & 2 & 3 & & 2 & 15 \\
\hline Anthony Reebok & 0.33 & 1 & 2 & & 2 & 1 & & 1 & & 1 & 1 & & 3 & 12 \\
\hline Yos Sudarso & 0.48 & & & 1 & & 1 & & & 1 & & 1 & & & 4 \\
\hline Imam Bonjol & 0.39 & 1 & & & 1 & & 1 & 1 & & 1 & 1 & 2 & 1 & 9 \\
\hline Total & & 30 & 421 & 28 & 40 & 33 & 38 & 35 & 28 & 31 & 60 & 39 & 65 & 468 \\
\hline
\end{tabular}

Source: Data on accident rate in 2019 [4] 
Table 3. Severity of human victims in 2019

\begin{tabular}{|c|c|c|c|c|c|c|c|c|c|c|c|c|c|c|}
\hline Road Segment & $\begin{array}{c}\text { Segment } \\
\text { Length } \\
(\mathbf{k m}) \\
\end{array}$ & Jan & Feb & Mar & Apr & May & Jun & Jul & Aug & Sep & Oct & Nov & Dec & Total \\
\hline Amahusu & 11.58 & 2 & 1 & 2 & & 2 & 2 & & 3 & 1 & 2 & 1 & 1 & 17 \\
\hline Dr. Malaiholo & 1.62 & 4 & 2 & & 3 & 2 & & & 2 & 2 & 1 & & 3 & 19 \\
\hline Dr. Kayadoe & 1.49 & & & 3 & & & 1 & & & 2 & 2 & 1 & 1 & 10 \\
\hline Dr. Tamaela & 0.35 & & 3 & 1 & 2 & & 1 & & 1 & & 1 & 1 & 1 & 11 \\
\hline Diponegoro & 0.62 & & & 1 & 4 & & & 2 & & 1 & 1 & & 2 & 11 \\
\hline Ahmad Yani & 0.54 & & & & & & 2 & & 3 & & 1 & & & 6 \\
\hline Rijaly & 0.64 & 1 & 1 & & 2 & & & 2 & & & 2 & 1 & & 9 \\
\hline $\begin{array}{l}\text { Jenderal } \\
\text { Soedirman }\end{array}$ & 2.90 & & 4 & 3 & 5 & 3 & 1 & 4 & 2 & 3 & 2 & 1 & 6 & 34 \\
\hline Pierre Tendean & 3.30 & 2 & 3 & 1 & 1 & 2 & 3 & 2 & 1 & 1 & 5 & 2 & 5 & 28 \\
\hline Wolter Monginsidi & 4.24 & 1 & 2 & 1 & 2 & 4 & 3 & & 3 & & 2 & 3 & 2 & 23 \\
\hline $\begin{array}{c}\text { Laksdya } \\
\text { Wattimena }\end{array}$ & 5.61 & 1 & 1 & & 3 & 4 & 2 & 1 & & 3 & 5 & 3 & 5 & 28 \\
\hline Ir. M. Putuhena & 9.23 & 1 & 2 & 2 & 1 & 2 & 3 & 2 & 1 & 2 & 3 & 3 & 5 & 27 \\
\hline Syaranamual & 3.42 & & 2 & 1 & 1 & & 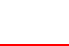 & 2 & & . & 3 & & 6 & 15 \\
\hline Sisingamangaraja & 3.25 & 6 & 1 & 1 & & & 3 & & 1 & 2 & 4 & 2 & 2 & 22 \\
\hline Dr. Leimena & 3.05 & 1 & 1 & & 2 & 3 & & 3 & & & 2 & 3 & 3 & 18 \\
\hline Dr. Siwabessy & 0.96 & 1 & 3 & 2 & & 3 & 1 & 1 & & & 3 & 2 & 1 & 17 \\
\hline Philip Latumahina & 0.41 & & & & & & 2 & 1 & & 1 & 1 & 1 & 1 & 7 \\
\hline Dr. Sitanala & 0.35 & 1 & & 1 & & & & & 3 & & 1 & 1 & 1 & 8 \\
\hline Sultan Baabula & 0.63 & & 1 & 2 & 1 & 1 & & & & 1 & 2 & 2 & 1 & 11 \\
\hline A.Y. Patty & 0.46 & 1 & 2 & 2 & 1 & 1 & 2 & 2 & 1 & 1 & 1 & 2 & 1 & 17 \\
\hline Said Perintah & 0.39 & & 1 & & & & 1 & & 1 & 1 & 1 & & 1 & 6 \\
\hline Pattimura & 0.55 & 1 & 3 & 1 & 2 & 1 & 1 & & & 2 & 2 & 3 & 3 & 19 \\
\hline Wem Reawaru & 0.18 & 3 & 1 & 1 & & & 3 & 1 & 1 & & 1 & & 1 & 12 \\
\hline Sultan Hairun & 0.47 & & 1 & & 2 & & & 2 & & 1 & & 2 & & 8 \\
\hline Kakialy & 0.29 & 1 & & 1 & & 1 & & 2 & 1 & & 1 & & 1 & 8 \\
\hline Tulukabessy & 0.39 & & 2 & & & & 2 & & & 1 & & 2 & & 7 \\
\hline $\begin{array}{c}\text { Sultan } \\
\text { Hasanuddin }\end{array}$ & 2.46 & & & & & & & 2 & & & 1 & & 2 & 5 \\
\hline Setia Budi & 0.53 & & & & 1 & & 1 & & 1 & & 1 & & 2 & 6 \\
\hline W.R.Suprtaman & 0.25 & & & & & & & 1 & & 1 & & 1 & & 3 \\
\hline Kapitan Ulupaha & 0.17 & 1 & & 1 & & 2 & & 1 & 1 & & 2 & & 1 & 9 \\
\hline Jan Paays & 0.31 & & & & 1 & & 1 & 2 & & 1 & 1 & & 1 & 7 \\
\hline A.M. Sangadji & 0.26 & & 2 & & 3 & & 2 & & 1 & 2 & 3 & & 2 & 15 \\
\hline Anthony Reebok & 0.33 & 1 & 2 & & 2 & 1 & & 1 & & 1 & 1 & & 3 & 12 \\
\hline Yos Sudarso & 0.48 & & & 1 & & 1 & & & 1 & & 1 & & & 4 \\
\hline Imam Bonjol & 0.39 & 1 & & & 1 & & 1 & 1 & & 1 & 1 & 2 & 1 & 9 \\
\hline Total & & 30 & 421 & 28 & 40 & 33 & 38 & 35 & 28 & 31 & 60 & 39 & 65 & 468 \\
\hline \multicolumn{15}{|l|}{ Remark: } \\
\hline \multicolumn{15}{|c|}{ Fatality death } \\
\hline \multicolumn{15}{|c|}{ Serious injuries } \\
\hline \multicolumn{15}{|c|}{ Minor injuries } \\
\hline
\end{tabular}


Table 4. Causes of Accidents of Ambon City in the 2019 period

\begin{tabular}{|c|c|c|c|c|c|c|c|c|c|c|c|c|}
\hline \multirow{2}{*}{$\begin{array}{l}\text { Causes of } \\
\text { Accident }\end{array}$} & \multicolumn{12}{|c|}{2019 Period } \\
\hline & Jan & Feb & Mar & Apr & May & Jun & Jul & Aug & Sep & Oct & Nov & Dec \\
\hline Drunkenness & 27 & 17 & 26 & 19 & 27 & 16 & 15 & 21 & 24 & 29 & 20 & 10 \\
\hline Drowsiness & 7 & 2 & 4 & 5 & 2 & 1 & 3 & 3 & 4 & 2 & 1 & 2 \\
\hline Recklessness & 23 & 12 & 16 & 14 & 18 & 7 & 11 & 13 & 12 & 19 & 12 & 5 \\
\hline Vehicles & 3 & 2 & 1 & 2 & 0 & 1 & 0 & 2 & 0 & 1 & 1 & 0 \\
\hline Road & 1 & 0 & 2 & 1 & 0 & 1 & 1 & 1 & 0 & 0 & 1 & 0 \\
\hline
\end{tabular}

\subsection{Causes of Accident Data}

The traffic accident data are classified according to the black site (road segment) in the 2019 period. Several factors cause accidents: drunkenness, drowsiness, recklessness, vehicles, and roads. The data used for traffic accident characteristics analysis in Ambon City. The results of compiling data based on various sources were shown in Table 4.

Based on Table 4, the cause of Ambon City accidents is dominated by motorist behavior that does not comply with the highway's driving rules [23]. Drunk driving was the leading cause of the accident rate at $53.40 \%$, followed by reckless driving at $34.47 \%$. The study results are the following studies conducted in Makassar City and several other Indonesia [2], [3]. Other contributing factors, such as drowsiness while driving, vehicle factors, and road conditions [24], are insignificant because each value is less than $10 \%$ [4].

\subsection{Weight Analysis of Traffic Accident Based on EAN and UCL Criteria}

An equivalent accident number (EAN) is one of the calculation methods to determine accident-prone areas. After knowing each parameter's value, the next step is to identify a section, including the locations prone to traffic accidents. By using control limits (UCL), it was expected that the results of the EAN value analysis can exceed the UCL standards.

The EAN value analysis results for all road conditions in
Ambon City in 2019 are presented in Table 5. This weighting uses the standards of the Indonesian National Police. Table 5 found five roads have the highest EAN value more than UCL value for 2019. The road segments are Jenderal Sudirman, Pier Tendean, Wolter Monginsidi, Laksdya Wattimena, and Ir. M. Putuhena. The five roads with the highest EAN scores than the UCL value were black site locations. These roads' physical characteristics generally have upward vertical alignment with sharp bends, and without medians or warning signs and lighting. When driving, users only rely on their vehicle sign lights. It is dangerous for motorists if crossing the road carelessly, even less if it is related to who often do not heed existing traffic signs or rules.

When road conditions are out of control, improvement needs proper knowledge and understanding - an education in the area around the black spot to protect themselves better. Public awareness is high to care for vehicles early that there is a desire to defend themselves. Educational efforts through outreach will further increase public awareness.

Black spot location is a specific location point in a black site area on roads in Ambon City. Locating stationing in an area (road segment) black site determines the black spot detail point. The accident number on the black site within a specified period, and road length divided by stationing length and the time interval studied. The following is a location analysis of the black site area and road length data in 2019, shown in Table 6. 
Table 5. Analysis of the 2019 EAN Value

\begin{tabular}{|c|c|c|c|c|c|c|c|c|c|c|}
\hline $\begin{array}{c}\text { Road } \\
\text { Segment } \\
\text { No. } \\
\end{array}$ & Road Segment & $\begin{array}{l}\text { Total } \\
\text { Death }\end{array}$ & $\begin{array}{c}\text { Total } \\
\text { Major } \\
\text { Injuries }\end{array}$ & $\begin{array}{c}\text { Total } \\
\text { Minor } \\
\text { Injuries }\end{array}$ & $\begin{array}{c}\text { Total } \\
\text { Victims }\end{array}$ & Death & $\begin{array}{l}\text { Major } \\
\text { Injuries }\end{array}$ & $\begin{array}{c}\text { Minor } \\
\text { Injuries }\end{array}$ & $\begin{array}{l}\text { EAN } \\
\text { Value }\end{array}$ & $\begin{array}{l}\text { UCL } \\
\text { Value }\end{array}$ \\
\hline 1 & Amahusu & 0 & 12 & 5 & 17 & 0 & 60 & 5 & 65 & 81 \\
\hline 2 & Dr. Malaiholo & 0 & 13 & 6 & 19 & 0 & 65 & 6 & 71 & 82 \\
\hline 3 & Dr. Kayadoe & 0 & 5 & 5 & 10 & 0 & 25 & 10 & 35 & 78 \\
\hline 4 & Dr. Tamaela & 0 & 8 & 3 & 11 & 0 & 40 & 3 & 43 & 79 \\
\hline 5 & Diponegoro & 0 & 7 & 4 & 11 & 0 & 35 & 4 & 39 & 78 \\
\hline 6 & Ahmad Yani & 0 & 5 & 1 & 6 & 0 & 25 & 1 & 26 & 76 \\
\hline 7 & Rijaly & 0 & 4 & 5 & 9 & 0 & 20 & 5 & 25 & 76 \\
\hline 8 & Jenderal Soedirman & 18 & 16 & $\mathbf{0}$ & 34 & 180 & 60 & $\mathbf{0}$ & 240 & 94 \\
\hline 9 & Pierre Tendean & 7 & 20 & 1 & 28 & 70 & 100 & 1 & 171 & 90 \\
\hline 10 & Wolter Monginsidi & 14 & 9 & $\mathbf{0}$ & 23 & 140 & 45 & $\mathbf{0}$ & 185 & 91 \\
\hline 11 & $\begin{array}{l}\text { Laksdya Leo } \\
\text { Wattimena }\end{array}$ & 15 & 13 & $\mathbf{0}$ & 28 & 150 & 65 & 28 & 243 & 95 \\
\hline 12 & Ir. M. Putuhena & 18 & 9 & $\mathbf{0}$ & 27 & 180 & 45 & 27 & 252 & 95 \\
\hline 13 & Sisingamangaraja & 8 & 12 & 2 & 22 & 80 & 60 & 2 & 142 & 88 \\
\hline 14 & Syaranamual & 0 & 10 & 5 & 15 & 0 & 50 & 5 & 55 & 80 \\
\hline 15 & Dr. Leimena & 2 & 14 & 2 & 18 & 20 & 70 & 2 & 92 & 84 \\
\hline 16 & Dr. Siwabessy & 4 & 11 & 2 & 17 & 40 & 55 & 2 & 97 & 84 \\
\hline 17 & Philip Latumahina & 0 & 3 & 4 & 7 & 0 & 15 & 4 & 19 & 75 \\
\hline 18 & Dr. Sitanala & 1 & 7 & 0 & 8 & 10 & 35 & 0 & 45 & 79 \\
\hline 19 & Sultan Baabula & 0 & 2 & 9 & 11 & 0 & 10 & 9 & 19 & 75 \\
\hline 20 & A.Y. Patty & 2 & 9 & 6 & 17 & 0 & 45 & 6 & 51 & 80 \\
\hline 21 & Said Perintah & 0 & 4 & 2 & 6 & 0 & 20 & 2 & 22 & 76 \\
\hline 22 & Pattimura & 2 & 9 & 8 & 19 & 20 & 45 & 8 & 73 & 82 \\
\hline 23 & Wem Reawaru & 0 & 5 & 7 & 12 & 0 & 25 & 7 & 33 & 77 \\
\hline 24 & Sultan Hairun & 0 & 4 & 4 & 8 & 0 & 20 & 4 & 24 & 76 \\
\hline 25 & Kakialy & 0 & 4 & 4 & 8 & 0 & 20 & 4 & 24 & 76 \\
\hline 26 & Tulukabessy & 0 & 4 & 3 & 7 & 0 & 20 & 3 & 23 & 76 \\
\hline 27 & Sultan Hasanuddin & 0 & 0 & 5 & 5 & 0 & 0 & 5 & 5 & 76 \\
\hline 28 & Setia Budi & 0 & 2 & 4 & 6 & 0 & 10 & 4 & 14 & 75 \\
\hline 29 & W.R.Suprtaman & 0 & 2 & 1 & 3 & 0 & 10 & 1 & 11 & 75 \\
\hline 30 & Kapitan Ulupaha & 2 & 5 & 2 & 9 & 20 & 25 & 9 & 54 & 80 \\
\hline 31 & Jan Paays & 0 & 5 & 2 & 7 & 0 & 25 & 2 & 27 & 76 \\
\hline 32 & A.M. Sangadji & 0 & 6 & 9 & 15 & 0 & 30 & 9 & 39 & 78 \\
\hline 33 & Anthony Reebok & 0 & 1 & 11 & 12 & 0 & 10 & 11 & 21 & 76 \\
\hline 34 & Yos Sudarso & 0 & 0 & 4 & 4 & 0 & 0 & 4 & 4 & 77 \\
\hline 35 & Imam Bonjol & 0 & 2 & 7 & 9 & 0 & 20 & 7 & 27 & 76 \\
\hline
\end{tabular}

Table 6. The black site road segment length data of Ambon City in 2019

\begin{tabular}{ccc}
\hline Black Site Area & Road Segment & Road Length $(\mathbf{k m})$ \\
\hline $\mathbf{1}$ & Jenderal Soedirman & 2,9 \\
$\mathbf{2}$ & Pierre Tendean & 3,3 \\
$\mathbf{3}$ & Wolter Monginsidi & 4,24 \\
$\mathbf{4}$ & Laksdya Leo Wattimena & 5,61 \\
$\mathbf{5}$ & Ir. M. Putuhena & 9,23 \\
\hline
\end{tabular}


The EAN analysis results in Table 5 shows that six roads are categorized as black site areas. The length of each road segment, as shown in Table 6, is used to determine accident-prone black spots with these results. The findings obtained from the black site area direct survey are essential to analyze all accident-prone areas in Ambon City. Road geometric of Jenderal Soedirman (black site 1) is a downhill or incline road. The road condition does not have a median or barrier between the two traffic lanes. It is one reason drivers are often negligent not paying attention to the lane dividing line and taking the driver's path from the opposite direction. Another cause of a black spot on Jenderal Sudirman road is that vehicles from both different directions rarely use low speeds when passing through this area. Traffic conditions where cars are prohibited from cutting off the flow, but people disobedience attitude, behaves to cut the flow without thinking other drivers, triggering an increase in accidents. There should be no movement of motorized vehicles on this route that reduces the two-way lane because it is hazardous for drivers against the current and those in the actual path.

The next black site location is the Pierre Tendean road segment. The road section area without side obstacles, and just relatively quiet, makes drivers drive their vehicles at high speeds. The minimum lighting also frequent factor accidents occur. Also, there are roads with steep curves and turns. Drivers who drive vehicles at high speed cannot control their cars, especially if they are drunk or sleepy. Motorists of productive age only carry out the behavior because they drain the springs from that location right at the pipe. A lot of wastewater on the roadside spreads to the asphalt surface so that the asphalt road is often potholes and bumpy. If you are in a downhill position and the vehicle is at high speed, it will be very prone to accidents.

Wolter Monginsidi road segment generally has flat road contours and a slightly uphill road contour. The people at this location are only on the east side because the west side is a beach with mangroves. The severe contours and slightly winding roads, coupled with lack of traffic signs, and awareness of both two-wheeled and four-wheeled riders, are feared to increase accidents.

At the black site, the Lakdsya Leo Wattimena road segment has land-use conditions, which are attractions for economic movements. The road with a three-way intersection is the cause of frequent accidents at this location. The road contours are straight, but the habit of stopping vehicles carelessly, and lack signs and control in the area, has made the people around the location unaware of traffic safety. The road is single access to the two crossing ports and many beach recreation areas in Central Maluku Regency.

While on Ir. M. Putuhena road segment has a new road section. The road section is connected to the Merah Putih Bridge, which connects the waters inside Ambon Bay. At night the street lights are still lacking at some point, so that the area very dark. It is dangerous if pedestrians want to cross because of lack of lighting (street lights) at night and the zebra crossing that is no longer visible on the road. Several bends, unmarked intersections, and people who do not obey the signs or are not careful when driving, also contribute to frequent accidents. The high mobility in this area is also triggered by land use around the road. The campus and residential areas on this road location will trigger the high accident victims at a productive age.

\section{Conclusions and Recommendations}

The high level of traffic accident severity in Ambon City $(91.95 \%)$ was caused by the driver's behavior factor. Three other factors that cause traffic accidents include drunkenness, recklessness, and drowsiness. Five black site areas on national roads in Ambon City based on the 2019 Equivalent Accident Number (EAN) value are roads: Jenderal Soedirman, Jalan Pierre Tendean, Wolter Monginsidi, Laksdya Leo Wattimena, and Ir. M. Putuhena.

Restricting movement (road medians build) intended to limit preparing vehicles movement, turning or cutting roads, and providing median openings at several points. Apart from restricting movement, the median existence also reduces vehicle speed significantly because it tends to low speed if there is no maneuvering area.

It necessary to make openings in the residential area to regulate the attraction movement, but they are placed in a limited manner. Append a crossing facility of a zebra crossing and completing it with refuge in the road median part. Complete the traffic signs installed with a sign that reads "Accident-prone." Append pedestrian facilities, sidewalks, and zebra crossings at road crossings. Place a protective fence to protect pedestrians. They are completing additional road markings on the roadside.

\section{Acknowledgments}

We appreciated Mr. Jon Sudiman Damanik, Head of Maluku National Road Implementation Center (BPJN Maluku), and Mr. Yanto Apul Sirait, Head of Planning and Monitoring Section of BPJN Maluku.

\section{REFERENCES}

[1] Mursalim, F. Chaeruddin, H. Halim, and Z. Saing, "Time value analysis of driver due to traffic jam during bridge construction: Case study in kalibone bridge construction Maros-Pangkep axis, Indonesia," Int. J. Adv. Sci. Technol., vol. 29, no. 5, pp. 3585-3593, 2020.

[2] H. Halim, R. Sultan, and Z. Saing, "Severity characteristics and identification of traffic accident prone areas in Makassar city," J. Adv. Res. Dyn. Control Syst., vol. 10, no. 2 Special Issue, pp. 2134-2141, 2018. 
[3] M. Manganta, H. Halim, A. B. Angka, and Z. Saing, "Traffic accident rate in Makassar city," Int. J. Sci. Technol. Res., vol. 8, no. 4, pp. 150-154, 2019.

[4] J. G. Metekohy, "Analysis of traffic accident characteristics (case study: Ambon City),” 2017. (in Indonesian)

[5] E. Republika, "Accident rate in 2019," Harian Republika, Jakarta, 2019. (in Indonesian)

[6] H. Widyastuti, M. Jufry, A. Riana, and Prabawati, "Valuation of road safety based on the type of road," in FSTPT International Symposium, UMS, 2013.

[7] L. Isen, A. Shibu, and M. S. Saran, "Identification and analysis of accident black spots using geographic information system," in Proceedings of the International Conference on Energy and Environment, 2013.

[8] Dušan Janković, Stojan Aleksić, "Traffic Safety on the Roads of Republika Srpska," Civil Engineering and Architecture, Vol. 6, No. 5, pp. 227 - 233, 2018. DOI: 10.13189/cea.2018.060501.

[9] Natalia Distefano, Salvatore Leonardi, "Evaluation of the Benefits of Traffic Calming on Vehicle Speed Reduction," Civil Engineering and Architecture, Vol. 7, No. 4, pp. 200 214, 2019. DOI: 10.13189/cea.2019.070403.

[10] Deddy Santoso, Tri Tjahjono, "Determination Minimum Distance between Ramp Entry and Exit on the Freeway Reviewed from the Road Safety Aspect," Civil Engineering and Architecture, Vol. 8, No. 3, pp. 268 - 273, 2020. DOI: 10.13189/cea.2020.080309.

[11] N. H. Dao, N. X., Son, P. H., Hoang, C. M., and Duc, "Vietnam road black-spot evaluation by accident schema: pilot study for a sub-urban area of Hanoi," in Proceedings of the Eastern Asian Society for Transportation Studies, 2013.

[12] B. H. Susilo, "Guideline for survey, investigation, and design of black spot location (SID-BSL) and its application in Lampung Province, Indonesia," Civ. Eng. Dimens., vol. 18 , no. 1 , pp. 49-56, 2016.

[13] M. B. Bolla, M. E., Messah, Y. A., and Koreh, "Analysis of traffic accident prone areas (case study of Timor Timur Kota Kupang Road)," J. Civ. Eng., vol. II, no. 2, pp. 147-156, 2013.

[14] H. Widyastuti, C. Mulley, and D. Dissanayke, "Binary choice model to value motorcyclist's slight injury cost in Surabaya,” J. East. Asia Soc. Transp. Stud., vol. 7, no. 1997, pp. 2674-2685, 2007.

[15] G. . Harahap, "Traffic problems and road development," 1995. (in Indonesian)

[16] Elyta, H. Almutahar, and Z. Saing, "National strength on construction of international freight terminal in entikong Indonesia," Int. J. Sci. Technol. Res., vol. 8, no. 3, pp. 10-15, 2019.

[17] A. S. Wedasana, " Analysis of accident-prone areas and compilation of databases based on geographical information systems (case study of Denpasar City)," Universitas Udayana, pp. 2091-2105, 2011. (in Indonesian)

[18] R.A.A. Soemitro, and Y. S. Bahat. "Accident analysis assessment to the accident influence factors on traffic safety improvement." Proceedings of the Eastern Asia Society for Transportation Studies. Vol. 5. 2005.

[19] V. Natalia Arung and H. Widyastuti, "Determination of Traffic Accident Prone Areas in the City of Surabaya," Jurnal Aplikasi Teknik Sipil, vol. 18, no. 1, pp. 17-22, 2020. (in Indonesian)

[20] M. F. Pradana, D. E. Intari, and D. Pratidina, "Analysis of traffic accidents and their causes on Cilegon roads," Jurnal Kajian Teknik Sipil, vol. 4, no. 2, pp. 165-175, 2019. (in Indonesian)

[21] D. Widiyanti, "Accident-prone area study in Musi Banyuasin Regency," Jurnal Transportasi Multimedia, vol. 14 , no. 2, pp. 67-76, 2016. (in Indonesia)

[22] Hamkah, R. Sihotang, V.Th.C. Siahaya, "Preliminary study on national road condition of Ambon City, Indonesia," Int. J. Adv. Sci. Technol., vol. 29, no. 5, pp. 10852-10866, 2020.

[23] H. Halim, I. Mustari, and Z. Saing, "Overtake behavior model of motorcycle on accident risk," vol. 29 , no. 5, pp. 12556-12567, 2020.

[24] M. Lukman, H. Halim, and Z. Saing, "The flatness levels of flexible road based on roadroid software in Perintis Kemerdekaan Street Makassar," IOP Conf. Ser. Earth Environ. Sci., vol. 419, no. 1, 2020.

[25] P2JN, "Data of Ambon City national road length," Ambon, 2020. (in Indonesian) 